\title{
Economic Adaptation Strategies of Coastal Communities Affected by Environmental Degradation (Study Case: Sayung Sub-district, Demak)
}

\author{
Arya Rezagama ${ }^{1}$, Sariffuddin ${ }^{2}$, Rudhi Pribadi $^{3}$, Syaria Fathi Bilqis Arneni ${ }^{2}$ \\ ${ }^{1}$ Environmental Engineering, Universitas Diponegoro, Indonesia \\ ${ }^{2}$ Urban Planning, Universitas Diponegoro, Indonesia \\ ${ }^{3}$ Marine Science,Universitas Diponegoro, Indonesia
}

\begin{abstract}
Sayung sub-district experienced the most severe abrasion impact in some villages. Abrasion not only drowns Rejosari and Tambaksari dukuh, but also shifts the pattern of life or social culture of coastal communities who choose no longer rely on the fishery sector ponds. The research used descriptive qualitative method that is research type which use description of field condition in writing. The type of questionnaire used is a questionnaire with open-closed questions (open-closed questions). The result is that $74 \%$ of Bedono local people feel that the environmental condition has worsened since the increasing of abrasion. The income level of Bedono local people as much as $60 \%$ of its citizens experienced a decrease in income level due to abrasion. Although, with the worse conditions caused by severe abrasion that damage the environment, local people of Sayung subdistrict have economic adaptation strategies to improve their financial aspect based on tourism development. On the other hand, the potential of Sayung Beach and surrounding areas to become Community Based Tourism is considered very unique.
\end{abstract}

Keywords: economic adaptation strategies; community based tourism; abrasion

\section{Introduction}

Sayung Sub-district is one of the important subdistricts in Demak Regency with an area of 7.869 hectares or $8.05 \%$ where the half of land area are experiencing severe abrasion [1]. The aforementioned abrasion was caused by sea water which was pushed up to the mainland due to the reclamation of Marina Beach and industrial development in Semarang which adjacent to Sayung Subdistrict [2]. Bedono is a village in Sayung Sub-district that is affected by the biggest abrasion compared to other areas in Demak Regency. This village has an area of 739.2 hectares in 1997 and the remaining 551,673 hectares [1]. The coastline of Bedono Village suffered a setback to the mainland, which in 2003 was $15.43 \mathrm{~km}$ long, changed to $10.54 \mathrm{~km}$ in 2009 , and $10.35 \mathrm{~km}$ in 2013. By 2017 the coastline, the retreats of the coastline to the mainland causing settlements and infrastructure facing directly to the sea to be often inundated by sea water, looks shabby, and the quality of the surrounding environment has decreased. Meanwhile, according to Damaywanti, abrasion in the village Bedono effect residents lost their homes [1]. At least until the year 2014, it was recorded that two neighborhoods (Hamlet Tambaksari and Rejosari Senik) have sank and must be relocated.

The objectives of this study are also include assessing public opinion of the environmental changes caused by rob, then examining the impacts of the environmental changes caused by rob on the communities' life quality and thirdly providing solutions to the concept of adaptation of people living in the area. As local term, 'rob' in this article refers to Buchori, et al who defined rob as inundation caused by the sea water overflow [3].

\section{Methodology}

The research applied descriptive qualitative method which is use description of field condition in writing. Various types of data that are descriptive then deeper analysis to make generalizations. The first phase of the study focused on finding secondary materials. The available literature on various aspects of the region (history, demography, economics, inheritance) is analyzed, especially in Indonesia related to tourism development for the region as a whole. Documentation of

*Corresponding author: arya_tl@ft.undip.ac.id 
the municipal archives was analyzed in relation to tourism and demographic evolution [4]. Direct collection method has been done through observation and in-depth interview. The questionnaire data was used in writing to sample of Bedono villagers as much as 100 respondents. The sample in this research is taken by using simple random sampling technique. Research sample was calculated using Slovin formula with $10 \%$ of error toleration. The respondent's characteristic is the Head of Family or one of the parents in the Village. The type used is a questionnaire with open-closed questions. Sampling results are processed by grouping answers from several questions asked. The results of data processing can be presented in the form of a graph that contains the number of each answer.

\section{Discussion}

The rob brings an influence on the economy of the villagers Bedono. More than $74 \%$ of Bedono villagers feel that the environmental condition has worsened since rob. The impact felt by the people of Bedono Village as a result of rob began to be felt by the people since 2005 until today. The occurrence of rob in the village Bedono caused by the rising sea level but accompanied by a decrease in soil surface caused by the development of coastal areas in the city of Semarang. As many as $47 \%$ of Bedono villagers believe that the rob could not be predicted so that the villagers of Bedono cannot anticipate the occurrence of rob whenever struck, then $25 \%$ of residents have a flood every day rob (see Figure 1).

Figure 1. The opinion About Rob's Environmental Condition; b. The opinion about the Cause of Rob; c. The opinion about Frequency Rob Occurrence

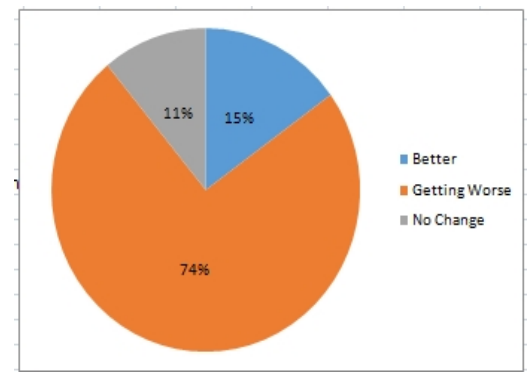

(a)

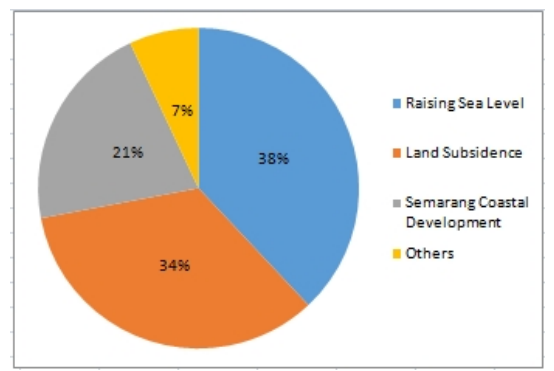

(b)

With environmental conditions demanding that Bedono villagers adapt to rob's floods, $78 \%$ of

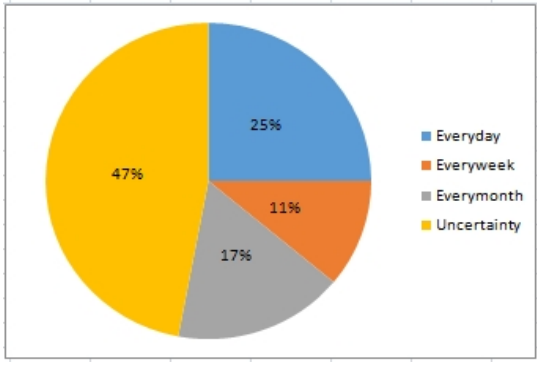

(c) respondents chose to stay but raised their homes so that rob water could not enter the house, but as many as $16 \%$ of respondents said not a few chose to move home due to a house that has been submerged by rob water. This causes, most of the houses are relatively high as houses on stilts. In addition to the environment, the occurrence of rob also gives impact to the financial aspects of citizens. As many as $60 \%$ of respondents said that income dropped dramatically due to the occurrence of rob. This is because the rob disaster eliminates livestock farms of citizens. The continued decline of fishery products is the impact of the change of community work from farmers to factory workers. In addition, the income level of Bedono villagers as much as $60 \%$ of its citizens experienced a decrease in income level due to rob. It can be concluded that rob disasters have a negative impact on the environment and economic conditions of villagers Bedono (see Figure 2).

Figure 2. The opinion Regarding Things to Do in the Event of Rob; b. The opinion Regarding Rob Land Condition; c. The opinion Regarding Income Condition of Villagers Since Rob Occurrence; d. The opinion Regarding Job Type Villagers
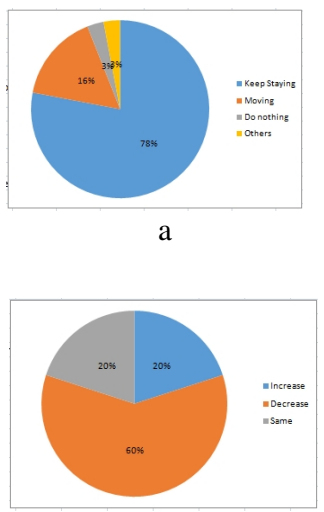

c.
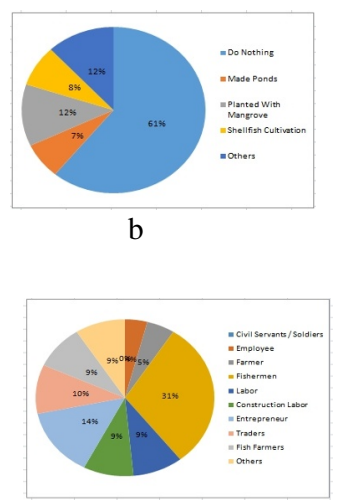

d.
The high salinity of the well was triggered by the change of land use of Desa Bedono. The high rate of abrasion of Bedono village caused the coastline retreat as shown above. In addition, in the opinion of respondents found that $74 \%$ of bad environmental conditions due to the occurrence of rob and abrasion. Another impact of rob is the decrease in shallow well water quality in Bedono village declining because of increased salinity, so residents use artesian wells to obtain adequate water consumption. As for getting water from the artesian wells, the residents must incur additional costs. Currently, almost all residents of Bedono village get clean water 


\begin{tabular}{|c|c|c|}
\hline Internal & $\begin{array}{l}\text { Strength (S) } \\
\text { 1. Sayung } \\
\text { location close } \\
\text { to the city of } \\
\text { Semarang } \\
\text { 2. Wide } \\
\text { mangrove } \\
\text { forest reaching } \\
4 \mathrm{Ha} \\
\text { 3. Religious } \\
\text { tourism object } \\
\text { Mbah } \\
\text { Mundzakir } \\
\end{array}$ & $\begin{array}{l}\text { Weakness (W) } \\
\text { 1. Public } \\
\text { Infrastructure are } \\
\text { always damaged } \\
\text { fast. } \\
\text { 2. Less powerful } \\
\text { village-level } \\
\text { institutions. } \\
\text { 3. Low income, } \\
\text { experience and } \\
\text { community } \\
\text { education }\end{array}$ \\
\hline $\begin{array}{l}\text { Opportunity }(\mathrm{O}) \\
\text { 1. Well known } \\
\text { tourist } \\
\text { attraction } \\
\text { 2. Government } \\
\text { aid programs. } \\
\text { 3. Focus on the } \\
\text { infrastructure } \\
\text { development }\end{array}$ & $\begin{array}{l}\text { 1. Increased } \\
\text { tourism } \\
\text { potential } \\
\text { through } \\
\text { Community } \\
\text { Base Tourism } \\
\text { related to } \\
\text { mangrove. } \\
\text { 2. Make } \\
\text { comprehensive } \\
\text { planning } \\
\text { related to } \\
\text { tourism object }\end{array}$ & $\begin{array}{l}\text { 1. Development of } \\
\text { suitable } \\
\text { infrastructure } \\
\text { with } \\
\text { environmental } \\
\text { conditions. } \\
\text { 2. Development of } \\
\text { income } \\
\text { alternatives of } \\
\text { citizens through } \\
\text { ponds, shellfish } \\
\text { farming, and } \\
\text { mangrove } \\
\text { business }\end{array}$ \\
\hline $\begin{array}{l}\text { Threat }(\mathrm{T}) \\
\text { 1. Sea level rise } \\
\text { will inundate } \\
\text { citizen } \\
\text { housing. } \\
\text { 2. Land } \\
\text { subsidence } \\
\text { 3. Mangrove } \\
\text { forests damage }\end{array}$ & $\begin{array}{l}\text { 1. To conserve } \\
\text { mangrove } \\
\text { forest area } \\
\text { 2. Conducting } \\
\text { rob } \\
\text { conservation } \\
\text { with sea } \\
\text { embankment, } \\
\text { hybrid } \\
\text { engineering } \\
\text { and other } \\
\text { technologies }\end{array}$ & $\begin{array}{l}\text { 1. Coordinate with } \\
\text { government, } \\
\text { universities, } \\
\text { private sector in } \\
\text { regional } \\
\text { development } \\
\text { 2. Establish } \\
\text { regulations } \\
\text { related to the } \\
\text { conservation of } \\
\text { coastal areas }\end{array}$ \\
\hline
\end{tabular}

supply from deep wells by installing connection in the Table 1. SWOT analyses of community-based tourism development in Bedono village

Form of piping channel and pay consumption cost routinely 2 weeks to 1 month. Deep well used is a well drilled with a depth between 80-138 meters so that water is considered feasible to be consumed. Water from deep wells is pumped using with power ranging between 800 1300 Watt. These deep wells are the private property of the people who are then distributed to the surrounding areas, as well as others that belong together on behalf of the local Mushala. The wells in the village of Bedono totaled 12 units.

Meanwhile, Bedono Village has the potential to be a Tourism Village with the concept of Community Based Tourism where in its implementation also empower the local community. According to Falak local communities are the most important stakeholder for the development of rural tourism [5]. The term Community-Based Tourism (CBT) describes an alternative form of tourism development that maximizes local benefits and advocates capacity building and empowerment as a means of achieving community development goals [6]. CBTrelated tops that have been documented in the literature include tangible benefits to local communities [7].
Bedono village has mangrove forest area of $9.4 \mathrm{Ha}$ which is still untouched by human and can be used as educational tour like mangrove edu-park. The form of tourism potential owned by Bedono Village consists of 4 types: educational tours in the form of Hybrid Engineering and Mussle Farming, religious tourism tomb Mbah Mudzakir, nature tourism mangrove forest, and culinary tourism. Tour packages are formed by reviewing and exploring the potential possessed by Dusun Bedono. In addition there is a positive side of the tour packages are managed by the community consisting of local communities, which can be tourists participated and invited around and follow the pattern of life of local communities.

Community Based Tourism invites visitors to find environmental problems, surrounding natural conditions, traditions, customs, and surrounding issues [8]. In addition, the determination and commitment of local communities to manage and conduct tourism activities in their homes is a determining factor in the success of the tourism business sector [9]. On the other hand, after the firmness and commitment, personality, personality and characteristics of the local community play a major role in the development of tourism [10]. To maintain the trust of tourists or tourists to come back, the community should also have knowledge about the attitude of hospitality, courtesy and tourism management [11]. However, the community will spontaneously learn to coordinate and cooperate between community leaders, members, and beginners [12]. In the other hand, the potential of Sayung Beach into Community Base Tourism is considered very unique. The Decree of the Minister of Marine Affairs and Fisheries No. 18 of 2004 on General Guidelines for the Implementation of Coastal Economy Economic Empowerment (PEMP) brings hope of change for the development of coastal areas based on community empowerment. Potential Desa Bedono will be explored in depth in order to be proper as Tourism Village by involving local people as workers in the tourism sector itself.

\section{Conclusion}

The rob disasters have a negative impact on the environment and economic conditions of villagers Bedono. The problem cause they should pay the water consumption more than common rate, public infrastructure damage fast, and bad sanitation condition. More than half of Bedono local people feel that the environmental condition has worsened and income level is getting down. On the other hand, the potential of Sayung Beach and surrounding areas to become Community Based Tourism is considered very unique. The form of tourism potential owned by Bedono Village consists of 4 (four) types: educational tours in the form of Hybrid Engineering and Mussle Farming, religious tourism tomb Mbah Mudzakir, nature tourism mangrove forest, and culinary tourism. Tourism activities undertaken by empowering the surrounding community as drivers, implementers, and tourism managers will foster the soul of independence and reduce the dependence of the community on the assistance of the 
Government of the majority of the character of charity and the impact of causing dependence.

\section{References}

1. K. Damaywanti, The Impact of Beach Abrasion on Social Environment (Case Study in Bedono Village, Sayung, Demak), (2013).

2. S. Aisyah, M. G. Rindarjono, C. Muryani, Analysis of Settlement Changes and Characteristics of Slum Settlements Due to Abrasion and Inundation in Coastal Kecamatan Sayung District Demak 2003-2013 (Journal of GeoEco Vol 1 No 1, 83 - 100, 2015).

3. I. Buchori, A. Sugiri, M. Mussadun, D. Wadley, Y. Liu, A. Pramitasari, I. Pamungkas, A predictive model to assess spatial planning in addressing hydro-meteorological hazards: A case study of Semarang City, Indonesia (International Journal of Disaster Risk Reduction 2017).

4. E. Ruiz-ballesteros, Community-building and amenity migration in community-based tourism development: An approach from southwest Spain (2016).

5. S. Falak, A repositioning strategy for rural tourism in Malaysia- community's perspective (Procedia Social and Behavioral Sciences, 412-415, 2014).

6. R. Dewi, Factors influencing community-based heritage sustainability in Kampung Kemasan,
Gresik (Procedia - Social and Behavioral Sciences, 498-502, 2016).

7. D. Tolkach, Strengthening Community-Based Tourism in a new resource-based island nation: Why and how? (Tourism Management, 386-398, 2016).

8. C. S. Kline, Using a community tourism development model to explore equestrian trail tourism potential in Virginia (Journal of Destination Marketing \& Management, 79-87, 2016).

9. M. P. Hampton, Power, Ownership and Tourism in Small Islands: Evidence from Indonesia (World Development, 481-495, 2016).

10. S. Moghavvemi, The effect of residents personality , emotional solidarity, and community commitment on support for tourism development, (2017).

11. P. V. Mathew, Impact of responsible tourism on destination sustainability and quality of life of community in tourism destinations (Journal of Hospitality and Tourism Management, 2017).

12. S. S. Trirat, Green Map : Agricultural Resources Management Tool for Community-Based Tourism (Procedia - Social and Behavioral Sciences, 248253, 2014).

13. S. Arieta, Community Based Tourism on Coastal Communities, Its Impact on Environment and Economic Empowerment (Journal of Maritime Dynamics Vol 2 No. 1, 71 -79, 2010). 